\title{
Roles and Challenges of Women in Tourism Sector of Western Nepal: A Micro- Ethnographic Study
}

\author{
- Sony KC \\ sonykayc@gmail.com
}

This paper examines the association of women and men in tourism, with particular focus on women's choices in picking roles, and challenges they encounter based on the roles they perform. This is a qualitative research paper based on the perceptions and expectations of women. It utilizes a month's field data from a few villages of Western Nepal. The information is extracted from key informant interviews, participant observations, focus group discussions along with existing literatures and policy document reviews. Findings reveal that roles are determined by factors such as education, family background, physical condition, language, and the ability to set one's own criteria. The gender-based roles are determined by demands of tourists and the demand for the nature of work. Unbearable workloads as referred to were undone dishes, laundry, children's demand and pressure from in-laws. Challenges such as lack of secure job, bullying by close relatives and the ultimate failure in balancing family and work were mentioned. Families were determined as the crucial role players in shaping the lives of these women who perceived that a little support from family members made their roles easier.

\section{Background}

The tourism sector of Nepal is one of the biggest opportunity providers contributing to the country's GDP through foreign exchange earnings and employment for women. This sector employs 200,000 people directly and about 1.2 million people indirectly (HAN, 2007). In the past, women working in this sector were more inclined towards domestic chores. The trend has changed now. Many have evolved as entrepreneurs, hotel owners, guides and porters. The evidences for this, however, 
are limited to reports, newspaper articles and media sources, with very little research available. The rise in women's status through such jobs provides a blissful outlook for Nepal bringing gender equity in terms of employment. Whilst considering the gender stereotypes still prevalent in Nepal, how these women balance their familial responsibilities with their work remains unnoticed.

Reports and reviews reveal that women's status has been gradually upgraded by exposure to jobs, but that they fail to address issues of dual roles and challenges. Theories of gender inequality reveal that women's stand in most of the conditions are different from men's owing to their treatment as unequal and underprivileged (Lengermann \& Niebrugge-Brantley, 2000, p. 462). This is also a reality very often seen and felt in Nepal. For example, Agrawal (1997) reveals that Nepali women hold less or no power relations in the sector such as community forestry while they are the ones who collect fodder and woods for living. Hence, their challenges remain unmentioned while men make decisions for them. Though women participate in the meetings conducted by the community forestry groups, they often do not speak out. Whether these factors exist for women in the tourism sector is a concern of this research. Likewise, the theories of gender oppression mostly examine the deep-rooted aspect of power relations in men and women in which men dominate, take control over and oppress women making them the bearers of abuse and crime (p. 470).

Also, women's needs and expectations have remained out of the boundary of research and debates. The Nepal Tourism Board (NTB) plays a major role in handling the issues of tourism with responsibilities to form policies and to organize promotional programmes. The importance of women in the tourism sector has been realized and many females are provided trainings to work as guides. However, findings from this research reveal that the inner tales of the tourism sector in relation to the worker's perception and expectations have not been considered seriously. Researches are rare in this direction. There is a lack of coordination between the service providers (NTB and other 
institutions that recruit women as workers or help formulate policies) and the service users (those serving the tourists).

Believing that every individual's perception counts, this paper analyzes the roles and challenges women face in comparison to men. The researcher attempts to listen to and bring out the voices of women involved in tourism sector. The main purpose here is to see whether there are challenges in working in the tourism sector or whether being a woman or a man matters in this field. With reference to previous researches (for example, Lengermann and Niebrugge-Brantley, 2000; Morais, 2005), which highlight domestic constraints as main deterrents to women's focused participation in tourism sector, this paper also examines whether such cases are prevalent today in the research sites.

\section{Methods}

Scope and Limitations: This paper reflects the voice of women and men working in the tourism sector, and includes their perceptions and expectations based on their experiences in the industry. The research sites were Landruk, Ghandruk and Chommrung lying in the Annapurna Conservation Area Project (ACAP). This paper also incorporates the perceptions of tourists and family members of those women (though limited in number as not every worker had their family members in the research sites) working in the tourism sector. An authentic and formal research on the gender-tourism aspects, especially in the case of Nepal, has not been carried out or is still at "an infant stage" (Upreti \& Upadhyaya, 2006). Hence, the researcher's attempt is to take the infant stage to one step further. Though grounded theory has been used which suggests the coining of new theories, this paper might not possibly coin new theories but provide few concepts and knowledge on why things are happening as they are. The findings included a month's field observation and interview of the informants involving approximately 50 women (major focus), 50 men, 50 tourists and some higher officials. Women and men workers, tourists and the officials involved in the tourism sectors were 
appropriate respondents for this research to understand the varied perception. They are linked directly and indirectly to the tourism sector and have some form of experience, perception or expectations based on their involvement. However, since this is a qualitative field study, the number of people did not matter as opposed to their voices and perceptions. Also, the number of respondents was totalled from those who were interviewed alone, and those who participated in focus group discussions and observation. Also, the interviews and discussions were stopped for time management once the objectives of this research were met.

Study Area: The Annapurna Conservation Area Project (ACAP) was founded in 1986 with an aim of conserving diversity and protecting those living within the boundaries of ACA. It welcomes $60 \%$ of the total number of tourists that enter Nepal every year (Shrestha, 2009). It holds world's largest rhododendron forest and highest lake with deepest gorge (ibid). The study areas Ghandruk, Landruk and Chommrung lie in the Kaski district of Nepal and fall in the ACA. ACAP covers the area of 7,629 square kilometres (Ojha and Sarker, 2012). The Ghandruk VDC falls in the altitude of 2,012 meters above sea level with a population of 5,138, among which 2,497 are males and 2,641 are females (Distrct Development Profile, 2011). Landruk (about 1620 meters) and Chommrung (about 2180 meters) are two small neighbouring villages of Ghandruk. These two villages are popular stop-over areas for tourists with a spectacular view of the Himalayas. The majority of people residing in these three villages are Gurungs.

Study Design and Method: This study follows an exploratory qualitative approach. An effective constructionist perspective was adopted to dig out the truth which is the most influential and sophisticated construction (Guba and Lincoln, 1989). Interpretation and descriptions were used to link the informants' reflections and their behaviourism.

In the autumn of 2010, women serving the tourism sector were selected for in-depth interviews. The interviews were conducted 
in an ethically friendly environment with no obstruction in interaction and reflection. Besides actor's consultation, focus group discussion, literature and policy document reviews and observations were used. A semi-structured questionnaire guide was created in Nepali language. Another questionnaire in English was created to interact with the tourists. The pre-testing was done with two guides during the researcher's visit to Pokhara. The questionnaire guide included information and queries related to roles portrayed, challenges faced while performing the roles and others that would meet the objectives. Use of tape recorders under the permission of the informants became a useful data collecting approach. In order to interview officials who run the tourism sector, appointments were set beforehand. The in-depth interviews were set to cover the time period of 30 minutes (though most of the interviews were put to an end before the estimated time in condition that the objectives of the research were met) while focus group discussions lasted for half an hour.

Data Analysis: A Grounded theory approach was an attempt of this thesis. Grounded theory has certain techniques like coding, creating memos, recording, interpreting the meaning and reporting them (Punch, 1998). The interviews conducted in Nepali were first transcribed and translated into English. An open coding was done in this research. In open coding information collected is identified, and highlighted based on its importance for the research, and is put into category (Strauss and Corbin, 1994). The analysis of the information derived from the open interaction follows the constructivist method further making an attempt to create new theories. This pattern deals with understanding human behaviour (Neuman, 2003) by giving them the opportunity to express. Also, a thematic approach was adopted while analysing the relevant quotes to derive theories out of them. Moreover, all the data collected were arranged according to the objectives and only information relevant or those that matched the objectives were extracted, transcribed and coded for data analysis. For example, the information given by the respondents were first listed and put 
under the appropriate headings, that is, roles, challenges, views about gender, knowledge on policies and insurance schemes and others. All those similar answers were singled out and different answers were taken based on the importance (evaluated by the researcher). The information not fitting into the research was excluded but some has been listed in the discussion/recommendation section. This also boosted the reliability and validity of this research.

\section{Findings}

The following themes were identified as overall findings: (1) dual roles and familial balance, (2) varied perception of gender and women working in the tourism sector of Nepal, (3) forms of challenges, (4) lack of proper policies and accessible benefits as causes of de-motivation.

\section{Dual Roles and Familial Balance}

Of the 50 women interviewees, 23 were guides between ages of 19-32 years; 8 were handicraft stall owners (age group 25-40), 6 porters (age group 29-32), 5 waiters in hotels (age group 2832) and 8 were hotel managers (age group 30-40 and over). Among the guides were 10 married and 13 unmarried; three of the handicraft stall owners were married, 6 porters married, 5 waiters of hotels married and 8 hotel managers married. Most of these informants were janjatis (Gurungs/Sherpas/Magars), few dalits and few from other castes such as chhetris. The majority of women were married who reflected dual roles, as reflected in the following descriptions by two of the respondents:

At this moment I am at work, carrying this load for tourists. I trek till ACAP region and get back in a week. I do not work during the weekends so I am with my family of four: my husband, a son and a daughter. When I am home, everyone wants to eat what I make, so this is what I do. My children complain of their father not cooking well (laughs). Sometimes, I want to 
rest but I cook and clean for the sake of my children. So, I play a role of a mother and a porter. (Married porter)

I have been working as a hotel manager since the year after I got married and came to Ghandruk. I have four children. In the beginning it was difficult to take care of them and manage the hotel at the same time. My inlaws and husband were supportive, but they indirectly suggested me not to get involved in these things. They always told me that I had to be a good mother than a good manager. There were times when my sons cried, I had to rush to them rather than wait and facilitate my customers. I used to lose many customers that way. But I did not care. For me my children are important. Now that they are grown ups, I have no problem. They understand me and help me with my work. My youngest son even helps me with better management skills.

Although most of the married informants stated that having a family is a blessing, they confessed it was a challenge when it came to working and maintaining familial balance. Fulfilling desires of family as a mother, a daughter-in-law and wife seems to be an ordeal for women working and taking care of household work. A gendered notion that women are good in household works (Shah and Gupta 1999) can occur from these statements as they mention how children love the food cooked by the mother than father. Also, women are socially and culturally expected to conduct household chores, given less decision making power in the family and generally suppressed under a patriarchal society. Married women were found to have been performing dual roles. The married porters would make a call once in a while to enquire about their children on various issues such as their school work, behaviours with the family members they were with and their eating habits. Though at work, they were performing the roles of caring mothers. In case of managers whose families were with them, observations showed that some advised their children to sit in front of them 
(where they were working) to do their homework after school, some gave their children some simple calculations like writing bills. Dual roles were performed well by these women with minimal complaint, but maximal enthusiasm and perseverance.

Additionally, even those unmarried could exemplify their friends working in the same sector by addressing to them as "dual role" players and tagging and teasing them playfully as "she is the man". The following excerpts help explain this:

I work five days a week as a guide. I loved to travel and so I wanted to become a guide. I am also a student in an open school which I have to attend only for exams. Otherwise working would be difficult. During the weekends, I stay at home, go out with my friends and relax. I do nothing but eat good food that my mother cooks, watch movies and just rest and get ready for the long week days. Unlike my friend here, who has three children, I do not have to rush home and worry about anyone. I am happy with my life. (Unmarried female agency guide)

I am busy only during the tourist season. Besides, I am a free person. There is not much to do. And that is when I take some time for myself. During peak hours, I work five days as a manager, and weekend is the time for washing and cleaning. My owner manages the hotel during the weekends. I cannot take offs at this moment and if I did it would be a mess. (Single female hotel manager)

Surprisingly, some of the single women, mostly guides, revealed their interest of not getting married anytime soon, and if they did they would quit working in this sector. One reason is that sometimes they have to work for 7 days a week due to demands of the tourists, and that continuing such work would not be appropriate for them after marriage. Though the differences between single and married women could be 
pointed out in terms of having children and families, it was also clear that these single women also performed chores such as washing clothes and dishes when free. For example, when tourists decided to spend their weekend in Ghandruk, the guides and porters flocked to wash their clothes. Interestingly, few (two) men guides and porters joined them to wash their clothes; while others had the hotels do the laundry for them in reduced price.

Though there was no need for the singles to maintain familial balance, there were few who reported about supporting their brothers or sisters in education, which still equals to maintaining familial balance. Marriage alone does not determine dual role or familial balance. The amount of responsibility and family background are the keys that add to marriage as well. Sometimes family members expect that their daughters support them through the earnings. Some family members are content that their daughter earns money and is financially independent.

\section{Varied Perceptions about Gender and Women in Tourism}

Some men, tourists and family members of those women working in the tourism sector appreciated women contributing to this field but some disapproved it.

Gender is denoted by being a male or female, where males are strong kind and females are the soft type. Females, after getting married are to be under the control of men and men are powerful in that sense because they control the family. If the female does not obey her male, she loses her values and has no respect in the society. This is what we have been following so far (Focus Group Discussion with women, Landruk)

Men and women are meant to be equal, but that is not the case. It happens only in countries like America or Belayat but here in Nepal women, mostly from the rural 
areas, have to live in hell if they choose to live independently. I work as a porter because it is difficult to sustain families if only one is working in the household. Hence to help my husband, I chose to do this job. I am not educated and the only thing I knew and was easy for me was choosing this field and carrying loads to sustain my life. I want to work as a guide or a hotel owner, but I cannot do so because I do not have the ability to please the tourists. (Female Porter, interview session Pokhara to Landruk)

Women's perception about gender came as one factor responsible for remaining within the social norms and creating home for their families. Males on the other hand were viewed as strong and controlling figure. Obeying a husband or males in the family is seen as respect that women tend to generate and from what they stated they appeared satisfied. Women holding this perception were mostly uneducated and could not speak good English. Other groups of women were those who worked as guides and were better qualified than the porters. They opined that males and females were both equal in all terms but social institutions and laws determined what women were to do in comparison to men. Their argument was that though the trend of gender inequality had been addressed by the government or non-government organisations, the unequal practice was still prevalent. Educated and married women workers expressed their sincerity towards their changes in life style after getting married, yet with poignancy they revealed that a woman's life would have been better if they went to a household where the husband's families cooperated and supported when they desired to work. Their idea that education does not seem powerful for a woman who is educated but has no supportive family (post-marriage) reflects a reality for a country like Nepal.

Likewise, men working in the same sector revealed their views as follows: 
Gender means male and female that god created. Initially women are meant to be the ones taking care of household and are motherly by nature. Men do all the strength acquiring works. But both are equal in their own stands...' (Group conversation with male guides, porters, hotel owners, Landruk)

We cannot cook well, but women are good in that. Why should they work outside? What are men for? This sector is not really for women. We do not have to worry about them going from places to places like what we see today. Little girls (like you) walk with the tourists. What if anything bad happens to them? Who will hold responsible? Yes, the culprit will be punished but the girl will lose her dignity. (Group conversation with guides, porters, hotel owners, Ghandruk)

Once again, the biological qualities are linked to the social attribution of women when men defined gender. The fact that women in the past actually did their household chores while their husbands worked for their living was stated by the informants, yet the notion of what has been mentioned as "strength acquiring works" denotes a boundary for women. While men performed the strength acquiring jobs, which was vividly noticed during the trek, women did not fail to do the same. Women carried more than 15 kilos of load from the base of the ACAP region barefoot and non-stop as if they were comfortable with their jobs. Therefore, definition of gender from men's perspective seemed as a mixture of the old and the new gender perception (or what we call the constructed gendered impression), where in the past women were the house leaders and nursed their babies. To stress on the phrase "losing dignity" when girls or women face serious problems denotes the social standing of Nepal and our prevalent practice. Societies still have not been able to see women working independently in the sectors like tourism or where they are to work in open environment. 
Most of the tourists commonly agreed that seeing women working makes the tourism sector livelier. They had a belief that women as guides or with other roles is a facet of change for Nepal and a great platform for them to grow. They expressed their contentment seeing women in this sector and wished it would grow more. Few tourists who visit Nepal regularly due to interest in trekking compared the past and present of this sector in terms of women working. They said,

I saw women only cooking and cleaning when I came here ten years ago, but it is amazing to see how thing have changed. The agency I dealt with has assigned a female guide and a porter with me in this trek and they are fun loving and wonderful. My guide is lively and speaks good English, better than me. My porter is a little lady but she carries heavy load. I feel ashamed sometimes to have to let her carry the entire load while I walk with just a back pack that weighs almost nothing. I watch her and feel sorry for her but she seems to like her job. I don't know. No complaints from her side...I mean, I would have been complaining about back pains if I were her. I ask her if I can help but she nods and smiles at me. She does not speak in English but shoots some words sometimes. I wish I had two porters who would divide the load into two and share the amount I pay. But we will see in the next ten years certain changes. (A Swiss tourist and a frequent explorer of Nepal)

Women working in this field are excellent and incredible. But what matters is the work load. No one can work for more than eight hours a day and most of us see women working more than that. They need someone else to replace their work after eight hours, especially during the season but we do not see that. Is it the money that they have to pay the workers? Also the load that women porters carry is way too much. Do they like carrying so much or do they get more pay if they do so? Both men and women do their jobs well but 
[we] prefer male porters to females. Other than that everything is great in Nepal. We love to be here and see beautiful women smile and help make our journey successful. (Group discussion with tourists in Landruk)

The informants showed their gratitude towards women and praised the latter. As they reflected and mentioned about porters carrying heavy loads, it was clear that female porters were carrying more than capacity. Also some tourists confirmed that women were working over time and they worked diligently. Positively, much has changed in the tourism sector as regards women and their engagement. There is still much to occur for their welfare. At this point, appreciating their work counts the most. Interestingly, when asked about porter and guide preferences, many tourists revealed they would choose male porters and female guides keeping it safe for both parties, further revealing that males are physically built and women facilitate well through their kind and gesture-filled speaking ability. Most tourists commonly agreed that women were to be careful about carrying heavy loads due to their biological built (some mentioned problems of uterus prolapse and other health challenges).

The family members of women working in tourism expressed their contentment and gratitude. They said they were proud and supportive of what the females were doing and earning. Some, especially children, stated about their mother going through difficult time when others in the family did not really approve of them working in that sector. Few women had made remarkable contributions in the lives of their children.

I do not come here often because of my studies. But I am happy that my mother earns like this. It is a lot of help. We have these stalls in Pokhara and my mother comes here during the tourist season. My father does the same thing but it was my mother's idea to run a stall. She is an active woman and supports mine and my brother's education by running the handicraft stall. I 
am proud to have a mother like her. She does not speak English that well but she has the ability to sell her products. I am amazed at her work (Daughter of a handicraft stall owner).

$\cdots$

It is because of my mother I am living this life. She sent us to a very good school. I still remember my paternal grandparents not letting her do the job of a lodge owner. They gave her names and made her cry so much. My father only drank and fought with her while she struggled. Now she is in this area and our lodge is the best with best food and facilities. (Youngest of four sons of the lodge owner/manager).

The children proudly admired their mother's work and her strenuous efforts in supporting their education. This gave an insight that a pinch of support would embolden women to become leaders. A concept that women are taking the position of men with the change in time can be derived from the aforementioned testimonies. Interestingly, some men assisted their wives best with work. Some children were frank enough to reveal the inside story pointing out to the domestic challenges faced by women working in the tourism sector.

\section{Forms of Challenges}

Besides the challenges underlying dual positions, women faced other forms of challenges. These include: maintaining power relations, bullying and harassment, difference in ethnic backgrounds and issues of citizenship.

Maintaining power relations: Most of the married women reported that they were deprived of the power of decision making due to familial interferences. Misunderstandings and giving bad names were prevalent when women did not agree to the decision makers: 
When I started living with my in-laws after he [husband] went abroad, my in-laws did not want me to continue college or work as a guide. I had a child then. I wanted to complete my BA....For four years I quit my studies and work. I started to work after my husband returned. For that we had to separate from our in-laws. I was given bad names by my in-laws and neighbours who stated that guides were bad, "uttaulo"[loose] women. I will join college again sometime soon but now I enjoy my work. What I mean to say is that my education had no power and was not valuable as I was deprived of my rights. A woman needs a support for such things. I am just an example; there are many friends of mine who are in the same boat (Guide, married).

Though knowledge can never be valueless, women's diligence is undermined due to deprivation and lack of support. The fact that women who try to work for a change are called "uttaulo" or given other names shows that the society still fails to value the role and contribution of women beyond the confines of families.

Bullying or harassment: The forms of bullying women reported were calling names such as "uttaulo," "sexy," "tourists' woman" and others. Both male and female informants revealed that they were bullied at some point. Surprisingly, the bullies were their own relatives rather than others.

I get frustrated especially when I and my friends get repeated comments from my relatives, like, "you look like a sexy heroine and good enough for a kuire". They laugh sarcastically. We do not flirt or anything. We just work as assigned by the agencies. Sometimes they even make me cry and I wish they had someone from their family, some girl, who worked in the same field. When they tease, it just spoils my day and I go to work with a bad mood. Every day I have to challenge myself to 
sneak out as early as I can so that my relatives or neighbours do not see me and start to gossip. Sometimes I feel like quitting this job, but for us women no place is free from bullies (Female guide) ...

My daughter says she goes to work as a guide. She often passes by our house when she has tourists with her. I hear her speak in English and I am proud because she is independent and takes care of me. Last year, with the money she earned, she bought me a gold ear stud. But people around us tell me that she is not in a good field. I have no idea what they are talking about. They take her name and tease "tero poi khai ta aaja, kuire haru chhainan" and sometimes when she is home during her days off, they say "aja poi khojna nagako" and laugh to which my daughter cries and I am there just muted. I feel really bad when my daughter has to go through all this. I am not literate even a penny and I do not know. We are from the village and maybe this job is not suited for village girls. I don't know. My daughter is not a prostitute and she is not doing anything like that. But when I see her cry, despite her hard work, I cry too. She is the son of this family."

The socio-cultural status of this area and lack of awareness about women working in the tourism sector makes people criticize them. The practice of generalizing and making false assumption is prevalent. For example, even in the city areas, if a lady is seen with a man, just talking or drinking tea, people give names as couple without realizing that they could be friends or even relatives. Or the fact that a lady in the back of the motorbike has to be the man's wife or a girlfriend is a prevalent mindset. Such practice and the way of generalizations are common in rural Nepali society and tourism has not remained an exception.

Ethnicity as a Challenge: Few women reported that their coming from different ethnic backgrounds was a challenge to work in this field. Though most of the informants were 
Sherpas/Magars/Gurungs, there were some ladies from dalit and chhetri communities, who experienced segregation from the majority groups.

I have been working in this field for a year now from an agency and it has been difficult to deal with other women. They are nice and they do talk to me but when it comes to sitting down together for lunch or dinner, I feel neglected. All other women that I know in this field are either Sherpas or Magars. They have their own circle of friends. I try to fit with them but they speak in their own language and I feel uninvited. Sometimes, I regret for choosing to work in this field. You need a friend, especially in the lodges and resting areas. Also most of the lodges are owned by the Gurung jatis and they treat the guides and others of the same caste better than than they treat someone like me" (Female guide).

Also what remains here is the identity issue. The "we feeling" within the people of various ethnic groups could be one of the reasons that makes them flock together. Also the difference in culture, as it is easy to communicate in one's own language than others and to practice one's own culture than others' brings people of identical ethnicity together. Language or cultural barriers pose a challenge for women in the tourism sector. However, these factors are more of a practice and people's choices or obligations than any rules or laws, which could affect the oddman out like in Mina's case.

Citizenship: A challenge or helplessness: Something unexpected and unnoticed, yet important for this research, was the citizenship issue as a challenge for those working in the tourism sector. I came across a number of refugees, who served the field selling handicrafts by setting stalls in the high hills. Out of eight such women, five were well-educated with a BA degree and the rest had completed high schooling. 
We are Tibetans but now nation-less. We respect Nepal for letting us stay but do not have citizenship. We cannot work even though we can go to college and get a degree. We pay for schools and colleges, yet we don't get jobs. Look at us, we are educated but helpless. To sustain our families, we have these shops. There are many like me. I am safe because my son will have a citizenship since my husband is a Nepali citizen. But what about others like me? My concern is not only about me but about others, especially women who want to do more. I have applied to go to USA and I cannot wait till the good days arrive (Group Discussion, handicraft stall owners).

The Tibet Justice Center reveals that 20,000 Tibetans reside in Nepal. These people do not have legal status. The future of these people seems bleak and insecure. Many children are born in Nepal and are "entitled under the international law to acquire a nationality." Hence, they remain devoid of country and future, and are often harassed by others. Some are even sent to Tibet. They live in a condition with limited political and economic rights with an undefined legal status (Tibetan Justice Center, 2002).

De-motivation: Lack of Policies and Accessible Benefits

Local organisations such as Committee for Lodge Management, Committee for Improvement and Preservation and Aama Samuha (Mother's Group) have remained active in the research sites. Also, the organizations dealing outside ACAP are, the Ministry of Tourism and Civil Aviation/Department of Tourism, Helvetas, the Department of National Parks and Wildlife Conservation and SNV/Nepal. The Nepal Tourism Board and various organisations such as Trekking Agencies Associations of Nepal (TAAN), Hotel and Handicraft Associations of Nepal, Three Sisters Agency and others have flocked to promote the tourism sector by empowering disadvantaged women, providing them trainings to work as 
guides, porters or hotel managers, and formulating plans and policies to assist the government bodies to improve the tourism sector. The Ministry of Women, Children and Social Welfare (MWCSW) remains a key body to promote gender equality and empowerment in women besides focusing also on children, elderly and ones with disabilities. Though this department works for women and children through the Women Development Offices, the agencies are reluctant to implement the proposed work due to lack of ample resources (ADB, 2010).

All the guides and porters were assigned from agencies, while some hotel managers owned their own hotels. Some of these new owners were guides in the past. This research identified that there is a gap between the supply and demand sides in the tourism sector. Very few women hesitantly reported about the flaws of agencies, but the tourists contributed more by pointing out such flaws. While the agencies tell their part, the tourists or the workers had their own stories. Examples:

We realized the importance of empowerment of women, especially those disadvantaged, poor and marginalised. Tourism sector is perfect for women of Nepal because the industry is huge and there is always need of workers. Not only this, women really lack knowledge about these things and what is most important is the transfer of knowledge. If we start training them with skills as soon as they enter the organization, then we are likely to face big failure. Then we move onto providing them with skills depending on what they want as training. We train them to achieve leadership quality in the beginning. Then we transfer them towards learning English, hiking, and interacting with each other. The training lasts for 3-6 months. Some women require more time (Agency Official).

It is not fair how these agencies work. I am a regular visitor to Nepal. I feel like I am neglected and my money is a full waste.... My female porter got sick, so I 
called the agency requesting not once, but thrice that I wanted a male porter because my female porter fell sick. I am supposed to be at ACAP today but I am stuck in Ghandruk till now. It seems like these agencies care for money more than customer service. You know why? Despite all that effort I made making phone calls, they sent me another female porter and on top of that they asked me to make a two days' payment of the previous porter who fell sick. She was with me only for a day and then she fell sick. I do not grow money and I am not responsible for her sickness. I do not understand. I am not making this trip until I get a male porter because I have a huge load and I do not want to see another female porter sick. Why are these agencies so careless? I really do not understand. It will be hard for me to console myself to visit Nepal again (Korean Tourist).

$\cdots$

We have insurance but we do not know how that really functions. None of us have claimed for it so far. Smital hurt her back and she was carried back to Pokhara. We do not know how she will take care of herself. Maybe the insurance will work. She is also like us. She does not know how to claim and what the procedures are. We just know the term insurance. (A female porter)

The three testimonies indicate that women empowerment is a fundamental issue for the tourism sector. However, empowerment alone does not suffice for meeting women's (or any worker's) needs. A protection mechanism along with its functional awareness is needed. Also, places to report crimes and harassment, encouraging women to report crimes and harassment to punish the perpetrators, keeping issues of harassment and penalties confidential are the major needs for women in this sector.

\footnotetext{
${ }^{1}$ Name changed for ethical consideration and Smita is the female porter who hurt her back while carrying load for the Korean tourist
} 
Few respondents (hotel managers and members of Aama Samuha of Ghandruk) reported that there is a lack of coordination between agencies and the government organisations. In one case, male lodge owners increased food prices in the menu against the rules from tourism board, but they were exempted any legal action. But when a female did the same, she was fined for it. A Managing Director of a trekking agency elaborated that the government's role is vital in the development of tourism industry. It should facilitate those who serve in the tourism industry and take them in confidence. But this demands a joint effort of organisations and agencies. A proper monitoring and evaluation mechanism does not exist, but it is a must for coordination between the government and the organisations involved.

The persons from the policy level, few of them approached for this research, agreed that the tourism sector needs reframed and refined policies covering the issues of gender and inclusion and job security mechanisms. And for such approach everyone involved in this sector has to be ready. One reputed government personnel stated:

Tourism sector is huge where we have to sort out many things before we set policies. We have some plans and polices and now and then we get to upgrade them based on the changes in the field, like the women involvement in this sector. We did not have many women in the past and now we do and we have to act accordingly. For now, we do not have a set plan only for women working in this sector because we still have to gather more information and data before going further.

When asked about the issues of harassment and the ways to get rid of them from the policy making side, one official answered: 
We are unaware about these issues but one thing is that we have done our best. It is often difficult to reach out to everyone and according to the information many women do not participate in the functions offered by the tourism board. Also it is always true that if there is anything that provides information to people, most of them do not go. This happens anywhere and we cannot force anyone. That is where they lack the information. Maybe the agencies they work with can conduct some sessions on such things.

This research vividly clarifies that there is a lack of coordination between the policy makers, agencies that provide employment and those involved in the tourism sector. However, approaching more officials from the policy level could have given more information in this area.

\section{Discussion}

This study explores the issues around women involved in the tourism sector and their status in terms of their roles, challenges and the existing policy interventions. This study has made an attempt to cover the issues of women working in the tourism sector, further signalling that there is need for more research under a similar theme. It has drawn perception of women, men, tourists, organisations and the government that are involved in the making of tourism industry of Nepal.

Most of the women reported that they would survive in the tourism industry as workers if their job was secured with proper schemes, and if there was coordinated support from the agencies they worked in and the government. Many expressed satisfaction from the point of view of empowerment but pointed the need of improvements as regards the welfare of all the workers (men and women) in the tourism sector. Though this research did not address the psychological aspects in these 
workers, it was known that harassment or bullying could manifest mental stress. Because, in the Nepalese society, if a woman loses her reputation she is ostracized leading to chaos in her life. For example, a previous study of women in a carpet industry in Nepal reported that 52 percent of women faced sexual harassment in their workplace with 61 percent affected mentally, 23 percent distracted from their work and 8 percent affected physically (Dhakal, 2009, p 1).

Also, many approved of being in comfort by working in this sector but what made them unhappy and discontent truly reflected on their perseverance with no fruitful future. For example, few women revealed that they put their strenuous effort to help tourists get to their destination but when they fall ill or meet other sorts of trouble, there have no support. Falling ill meant huge loss for their family and sustaining their livelihood and they could not afford it. Thus, the tourism sector pries for some form of security mechanism for the workers.

This study covers very little on the coping strategies by women in the tourism sector. Women reported that they did the following when they were stressed due to work hassles such as bullies by others, and dissatisfaction about the payment (applied to guides and porters mostly): (1) letting it go or tolerating it (2) sharing with friends and colleagues, (3) sharing with family members. There were no signs of rebelling or filing complaints due to lack of knowledge on how or where to lodge complaints. Some women also reported that they did not even have time to file any complaints and they assumed that such actions would be time-consuming. Some women revealed that they ignored bullying and harassment thinking that if their information leaked, it would lead to an issue of dignity. Thus, maintaining dignity became highly important.

The porters reflected that education mattered for better jobs in the tourism industry. It was noticeable that women with better education and English speaking ability were guides and those who did not do well with English were porters. Language 
mattered in pursuing roles and roles were determined by an individual's ability to speak a foreign language. This connects us to the evidence that there are still two thirds of people in this world that are uneducated and they are women (Kiray, 2009). Pritchard et al (2007) have stated that men and women differ in terms of their occupations in the tourism sector given the fact that the jobs that women perform mirror the household chores or "the traditional domestic roles" they perform (p 6). However, this has changed in the tourism sector of Nepal with increasing diversity in roles beyond the confines of the household Apart from household chores, women have emerged with various roles.

Also, tourists prefer males when it comes to employing porters. Fifty tourists (20 male, 24 female) were asked about their preference on male/female guides and male/female porters. Fourteen female tourists preferred female guides and male porters while 3 male tourists preferred the same. Sixteen male and 5 female tourists reported it did not matter and 1 male tourist as opposed to 5 females preferred male porter and male guide. The ones who said it did not matter were those who mostly travelled independently. Most of the females were concerned about the loads and the distance of walking. This reflected that roles were determined by the ability of the workers to bear the works.

From the policy level, it is clear that the tourism sector's policy needs refinement and worthwhile workout. For now, the policies are mostly inclined towards facilitating the tourists and making them comfortable and happy. The policy slightly mentions about insurance schemes and women empowerment but fails to address the issues of human security (in this case women's safety from bully and harassment, their payment and health insurance scheme, their financial, social and psychological being) in a holistic approach. Hence, much 
Figure 1: Guides and Porters: Preferences on the basis of Gender

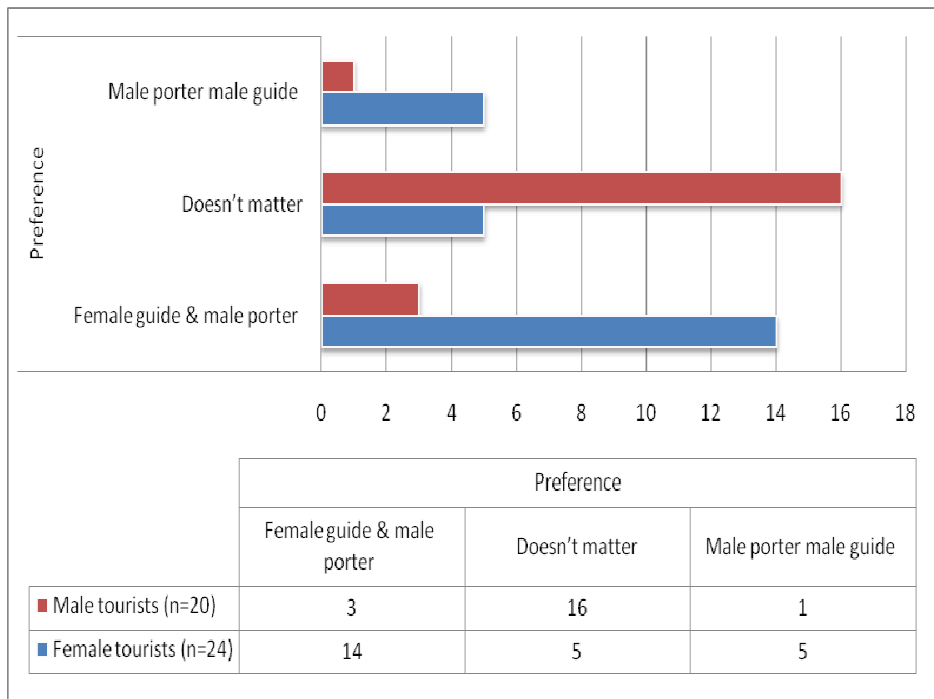

research is needed to understand the state of women and men workers in the tourism sector, their needs to frame policies and undertake actions. The Global Report on Women in Tourism 2010 draws attention that if the aspects of gender are considered in the policies, plans and implementation this sector would promote gender equality (UNWTO and UNIFEM, 2010). This shows that tourism sector all over the world still needs special attention in regards to integrating gender issues in the policies. This gives a notion that in the current situation where Nepal's tourism sector brings huge currency and the workers involved in facilitating the tourists are women, it is more likely that policies should be gender-sensitive.

This paper's major input lies in complementing what few researchers such as Shah and Gupta (2000) in Tourism, the poor and Other Stakeholders: Experience in Asia miss mentioning the roles women play in tourism sector, especially the rampant gender biases. I believe my contribution here has been to level up the study from "infant stage" to at least the level of a toddler. 


\section{Concluding Remarks}

Women have proved to be the agents for building capacities of resources in tourism sector in comparison to men. Hence, it is crucial that the degree of problems faced by women in the tourism sector requires quantification along with the qualitative approach of a study as this. Since there are no data sources on the actual number of women contributing to the tourism sector in various roles, a proper categorisation is lacking. There is an urgent call to determine the exact number of women working in the tourism sector in order to make plans and policies to address their work-needs that are unidentified and unaddressed so far. Quantifying and categorising women and their needs based on their roles will provide an illuminated analysis for better use of information in policies and programmes related to tourism sector.

Much needs to be done from the supply side (government, agencies and other related organisations) to uplift women not only in the name of empowerment but in the name of protecting them with social protection mechanisms such as insurance, security from external harm and their well-being on becoming the ones who served the largest industry of Nepal. This study brings to existence the impact of exclusion on women despite the rise in concept of empowerment of Nepalese women. It is very important to therefore, address the major challenges they face in order to comfort them and support them for improved living.

\section{Acknowledgements}

The research for this publication was conducted within the framework of the Working Package 1 of the Swiss National Centre for Competence in Research (NCCR) North-South: Research Partnerships for mitigating syndromes of Global Change, co-funded by Swiss National Science Foundation and Swiss Agency for Development and Cooperation. I would like to thank all the women, men, tourists and officials working in 
the Annapurna Conservation Area Project (ACAP), especially in the areas from Pokhara to Ghandruk, Landruk and Chommrung for contributing their valuable time in the making of my research. I thank Dr. Sagar Raj Sharma for shaping my career as a researcher while going through career crisis. My utmost gratitude goes to Dr. Bishnu Raj Upreti for believing in me and appreciating my work. My sincere thankfulness goes to Dr. Mahesh Banskota for providing me a great opportunity to disseminate my research findings from this platform.

\section{References}

ADB. (2010). Overview of gender equality and social inclusion in Nepal. Kathmandu, Nepal.

Agarwal, B. (1997). Environmental action: Gender equity and women's Participation. Development and Change, 28, 1-43.

Dhakal, G. (2009). Women's experience of sexual harassment in carpet factories. Journal of Nepal Health Related Council, 7 (2).

District Development Profile of Nepal. (2010/2011). A socioeconomic development database of Nepal.

Kathmandu: Mega Publication \& Research Centre (MPRC).

Guba, E. G., and Lincoln, Y. S. (1989). Competing paradigms in qualitative research. In N. Denzin and Y. Lincoln (eds.), The landscape of qualitative research (pp 150200). London: Sage Publications.

Gupta V., and Shah, K. (2009). Tourism in the Himalayas:

Seizing the opportunity in gender and tourism:

Women's involvement in tourism planning and management. Gender Digest, 19 (March 2009). 1-9.

Gurung, G. (2010). Tourism and development. Retrieved May

2, 2010 from http://ghandruke.com/pages/tourism.html. Hotel Association of Nepal. (2007). Annual report. Kathmandu. Kiray, E. (2009). Social Campaign for gender-related issues in Turkey. Izmir University of Economics. 
Lengermann, M. P., \& Niebrugge-Brantley, J. (2000).

Contemporary feminist theory. In G. Ritzer (ed.), Sociological theory (pp. 447-496). McGraw Hill International

Morais, B. D. (2005). How is tourism affecting ethnic minority women? The case of Bai and Mosuo women in Yunnan Province, PRC. Digital Traveler, 1-3. The International Ecotourism Society (TIES). Retrieved February 3, 2010, from www.ecotourism.org.

Neuman, W. L. (2003). Social research methods: Qualitative and quantitative approaches $\left(5^{\text {th }}\right.$ ed.). Boston: Allyn and Bacon.

Ojha, P. A, and Sarker, K. T. (2012). Effectiveness of the integrated conservation and development program (ICDP) in conserving wildlife in the Annapurna Conservation Area in Nepal. International Journal of Biodiversity and Conservation, 4 (6), 237-242.

Punch, K. F. (1998). Introduction to social research: Qualitative and Quantitative approaches. California: Sage Publications.

Shrestha, A. (2009). Ghandruk, Nepal: Sustainable village-50 years planning. Retrieved August 10, 2012 from www.nrndk.com/resources/Ghandruk.pdf

Strauss, A., and Corbin, J. (1990). Basics of qualitative research: Grounded theory procedures and techniques. Sage Publications.

Tibetan Justice Center. (2002). Tibet's stateless nationals: Tibetan refugees in Nepal. Retrieved December 12, 2012 from http://www.tibetjustice.org/reports/nepal.pdf.

Upadhaya, P.K., and Upreti, B.R. (2008). Enhancing women's participation in mountain tourism, prospects and challenges. Retrieved from http://lib.icimod.org/record/13555/files/1265.pdf .

UNWTO and UNIFEM. (2011). Global Report on Women in Tourism, 2010. Preliminary Findings. Retrieved from http://www2.unwto.org/sites/all/files/pdf/folleto_globar 1_report.pdf 